\title{
PELAKSANAAN ALIH TEKNOLOGI MELALUI PERJANJIAN LISENSI PATEN BERDASARKAN UNDANG- UNDANG NOMOR 13 TAHUN 2016
}

\author{
Yurida Zakky Umami \\ Universitas Wahid Hasyim Semarang \\ yuridazakkyumami@unwahas.ac.id
}

\begin{abstract}
ABSTRAK
Alih teknologi mempunyai peran penting di bidang industri, terutama untuk menghadapi globalisasi dunia. Salah satu mekanisme alih teknologi dapat dilakukan melalui perjanjian lisensi. Melalui perjanjian inilah dapat dilakukan pengalihan paten. Perjanjian lisensi berdasarkan Pasal 1 ayat 11 Undang-Undang Nomor 13 Tahun 2016 tentang Paten, hanya merupakan izin yang diberikan oleh Pemegang Paten kepada penerima lisensi berdasarkan perjanjian tertulis untuk menggunakan Paten yang masih dilindungi dalam jangka waktu dan syarat tertentu, untuk menikmati manfaat ekonomi dari paten tersebut. Pengaturan perjanjian lisensi paten terdapat pada Pasal 76 sampai dengan 80 Undang-Undang Nomor 13 Tahun 2016. Perjanjian lisensi alih teknologi wajib menyertakan ketentuan know how dan tentang pembayaran royalty. Keunggulan dari alih teknologi melalui perjanjian lisensi adalah lebih mudah untuk memasuki pasar internasional dengan menghemat biaya dan waktu, serta dapat memperoleh pengetahuan mengenai teknologi secara lebih cepat, sedangkan kelemahannya adalah terbentuknya kompetitor, terbatasnya royalty, dan sering terjadi konflik pada saat pelaksanaannya.
\end{abstract}

\section{A. PENDAHULUAN}

Tujuan pembangunan dalam bidang ekonomi nasional bertujuan untuk mewujudkan struktur ekonomi yang seimbang dimana terdapat kemampuan dan kekuatan industri yang maju. Bangsa Indonesia dalam melaksanakan pembangunan nasionalnya saat ini telah menempatkan prioritaspembangunan pada bidang ekonomi yang menitikberatkan padapenguatan dan pendalaman struktur industri yang mendukungkemampuan teknologi. Hal ini bertujuan agar bangsa Indonesia lebih terpacu untuk mewujudkan tujuan pembangunan nasional atas dasar kekuatan sendiri, sehingga Indonesia mampu dalam memasuki era globalisasi. Melihat dari tujuan pembangunan tersebut, khususnya yang berkaitan dengan usaha dalam membangun kekuatan industri, faktor yang perlu 
diperhatikan adalah kebutuhan di bidang teknologi.Faktor ini penting, karena teknologi merupakan faktor penentu dalam pertumbuhan dan perkembangan industri. $^{56}$

Teknologi di era globalisasi seperti sekarang ini telah megalami kemajuan yang sangat pesat. Hal ini ditandai dengan banyaknya penemuan teknologiteknologi baru oleh negara-negara maju seperti Amerika, Eropa dan beberapa negara Asia lainnya seperti, Jepang dan Korea. Negara-negara tersebut sedang gencar-gencarnya melakukan research dan development $(R$ and D) untuk mengembangkan produk-produknya, dan berhasil menerapkan teknologi yang mutakhirdengan proses yang lebih rumit, dan sistem yang lebih canggih. Negara yang sedang berkembang seperti Indonesia, yang saat ini masih dalam usaha untuk memperkecil jarak ketertinggalan dalam bidang teknologi, dibandingkan dengan negara-negara maju yang terus-menerus menemukan teknologi-teknologi baru.

Industri di Indonesia tidak memiliki pilihan selain harus mengikuti dengan kemajuan teknologi paling mutakhir, agar produksinya dapat bersaing dengan hasil produksi negara-negara maju.Teknologi dalam bidang ekonomi biasa diartikan sebagai the application of scientific knowledge to the production of industrial goods and improvement of service. ${ }^{57}$ Pada suatu teknologi terdiri dari berbagai jenis hak ataskekayaan intelektual salah satunya adalah paten yang memiliki peran penting bagi teknologi dan industri, dan sekarang telah berkembang dalam bentuk perjanjian lisensi antara pemegang paten dan penerima paten.

Melihat dari kondisi tersebut bagi Indonesia sebagai negara yang sedang berkembangtidak mempunyai pilihan lain untuk menuju kepada struktur ekonomi yang kuat dan berkelanjutan. Oleh karena itu, pemerintah Indonesia membuka diri untuk penanaman modal dari luar dengan melakukan perjanjian Penanaman

\footnotetext{
${ }^{56}$ C.S.T Kansil, Hak Milik Intelektual, Paten, Merek Perusahaan, Merek Perniagaan, Hak Cipta, Bumi Aksara, Jakarta, 1990, hlm 5.

${ }^{57}$ Insan Budi Maulana, Ridwan Khairani, Nurjihad, Kapita Selekta Hak Kekayaan Intelektual I, Yogyakarta, 2000, hlm 55
} 
Modal Asing (PMA), salah satunya melalui alih teknologi dari luar ke dalam negara Indonesia. Alih teknologi merupakan pengalihan kemampuan memanfaatkan dan menguasai ilmu pengetahuan dan teknologi antar lembaga, badan, atau orang, baik yang berada dilingkungan dalam negeri maupun yang berasal dari luar negeri ke dalam negeri dan sebaliknya ${ }^{58}$.

Alih teknologi (transfer of technology) mempunyai peran penting di bidang industri, terutama untuk menghadapi globalisasi dunia. Hal ini telah menjadi isu sentral antara negara maju dan negara berkembang, terlebih setelah lahirnya suatu organisasi dunia World Trade Organization di tahun 1994. Salah satu mekanisme alih teknologi dapat dilakukan melalui perjanjian lisensi. Melalui perjanjian inilah dapat dilakukan pengalihan paten. Perjanjian lisensi berdasarkan Pasal 1 ayat 11 Undang-Undang Nomor 13 Tahun 2016 tentang Paten, hanya merupakan izin yang diberikan oleh Pemegang Paten kepada penerima lisensi berdasarkan perjanjian tertulis untuk menggunakan Paten yang masih dilindungi dalam jangka waktu dan syarat tertentu, untuk menikmati manfaat ekonomi dari paten tersebut.

\section{B. PEMBAHASAN}

\section{Pengaturan Alih Teknologi Melalui Perjanjian Lisensi Paten}

Alih teknologi adalah pemindahan teknologi dari pemilik teknologi kepada penerima teknologi untuk mengadaptasi teknologi tersebut. ${ }^{59}$ Teknologi disini merupakan metode serta proses atau produk yang dihasilkan dari penerapan dan pemanfaatan berbagai disiplin ilmu pengetahuan. ${ }^{60}$ Peralihan teknologi dapat ditempuh dengan dua cara yaitu, melalui penanaman modal, dan melalui perjanjian lisensi paten. ${ }^{61}$ Akan tetapi, peralihan teknologi melalui pemberian lisensi dipandang lebih baik, karena penerima lisensi dapat belajar untuk

\footnotetext{
${ }^{58}$ http://kip.bppt.go.id,/index.php?option=com_content\&view=article\&id=768\&Itemid=248

${ }^{59}$ Romli Mubarok. 2007. Alih Teknologi Melalui Perjanjian Lisensi Kaitannya dengan UndangUndang Nomor 14 Tahun 2001 Tentang Paten. Hukum Dan Dinamika Masyarakat. Vol.5 No.1. Hlm. 7

${ }^{60} \mathrm{Ibid}$.

${ }^{61}$ https://ramadhanmuawad.wordpress.com/2016/07/14/bentuk-dan-cara-alih-teknologi-berkaitandengan-penanaman-modal-asing/
} 
melaksanakan sendiri Hak Atas Kekayaan Intelektual dalam bentuk teknologi yang dilisensikan tersebut. Penerima lisensi diharapkan dapat melakukan modifikasi, pengembangan dan penyempurnaan lebih lanjut dari teknologi yang dilisensikan, serta kemudian memiliki sendiri teknilogi yang handal, yang menjadi bagian dari Hak atas Kekayaan Intelektual yang dimiliki olehnya sendiri.

Pengaturan perjanjian lisensi paten terdapat pada Pasal 76 sampai dengan 80 Undang-Undang Nomor 13 Tahun 2016. Pada pasal tersebut menyatakan bahwa Pemegang Paten berhak memberikan Lisensi kepada pihak lain berdasarkan perjanjian Lisensi baik eksklusif maupun non-eksklusif untuk melaksanakan perbuatan untuk melaksanakan Paten yang dimilikinya dalam jangka waktu tertentu, dan melarang pihak lain menggunakan paten tersebut tanpa persetujuannya.

Perjanjian Lisensi dilarang memuat ketentuan yang dapat merugikan kepentingan nasional Indonesia atau memuat pembatasan yang menghambat kemampuan bangsa Indonesia dalam melakukan pengalihan, penguasaan, dan pengembangan teknologi. Perjanjian ini harus tercatat dan diumumkan oleh Menteri dengan dikenai biaya. Jika tidak tercatat dan tidak diumumkan sebagaimana mestinya, maka perjanjian tersebut tidak mempunyai akibat hukum terhadap pihak ketiga.

Lisensi paten ini dilaksanakan dengan sistem perjanjian dimana yang sering digunakan adalah kontrak dengan sistem kontrak baku. ${ }^{62}$ Acuan peraturan yang digunakan dalam kontrak baku ini adalah pasal 1320 KUH Perdata mengenai syarat sahnya perjanjian, pasal 1338 KUH Perdata mengenai asas kebebasan berkontrak, pasal 1234 KUH Perdata mengenai prestasi, dan pasal 1365 KUH Perdata mengenai perbuatan melawan hukum pada perjanjian.

\section{Ketentuan dan Syarat Alih Teknologi ${ }^{63}$}

Penyerahan suatu atau beberapa hak teknologi melalui perjanjian lisensi dari pemegang paten kepada penerima paten perlu ditundukkan pada sejumlah

\footnotetext{
${ }^{62}$ http://kurniowen.blogspot.com/2012/06/kontrak-lisensi-alih-teknologi-di.html

${ }^{63}$ Ibid.
} 
ketentuan dan syarat yang harus dipenuhi oleh kedua belah, karena melalui ketentuan dan syarat tersebut hak (keuntungan yang diharapkan) dan kewajiban (pengorbanan) masing-masing pihak ditetapkan seimbang dan adil. Diantara berbagai ketentuan dan syarat tersebut yang perlu mendapat perhatian utama diantaranya:

a. Eksklusifitas atau non-eksklusifitas

Pemberian dan penerimaan lisensi dapat bersifat eksklusif dan noneksklusif, dapat ditinjau dari pemegang paten atau penerima patendengan kepentingan yang berbeda-beda. Untuk kepentingan pemasaran yang luas, pemegang paten biasanya menghendaki pemberian lisensi yang non-ekslusif, sehingga lisensi itu dapat digunakan oleh lebih banyak penerima peten.

b. Pembatasan jenis kegiatan

Biasanya lisensi tidak diberikan tanpa batas, dan pembatasan tersebut dapat ditentukan dengan berbagai cara diantaranya:

1) penerima paten dapat menerima hak know how untuk memproduksi serta menggunakan merek dagang untuk menjual produk yang bersangkutan.

2) penerima paten dapat menerima hak know how untuk memproduksi, tetapi hak menggunakan merek dagang diberikan kepada penerima paten lain guna memasarkannya.

Know how dapat didefinisikan sebagai pengetahuan teknis atau organisasi yang memiliki kekhasan dalam bidang industri. ${ }^{64}$ Know how merupakan akumulasi pengetahuan dan pengalaman keterampilan praktis atau keahlian dan informasi untuk menjalankan segala bentuk prosedur dan proses suatu produk. Menyertakan ketentuan know how pada perjanjian lisensi paten merupakan hal yang penting untuk dilakukan, karena tanpa adanya ketentuan tersebut dapat dipastikan akan mengalami banyak hambatan dan hampir tidak mungkin dapat menguasai teknologi yang dipatenkan tersebut, karena tidak semua pengetahuan untuk melaksanakan paten tersebut diuraikan dalam deskripsi paten yang bersangkutan.

${ }^{64}$ Insan Budi Maulana, Ridwan Khairani, Nurjihad, Op Cit, hlm 57 


\section{Pembayaran Imbalan atau Royalty}

Pembayaran royalty merupakan subsistem terpenting, karena bagi pemberi lisensi, royalty adalah imbalan baginya karena telah menghabiskan waktu, biaya, dan percobaan untuk memperoleh penemuan baru tersebut. Oleh karena itu, mengenai pembayaran royalty harus dirumuskan dalam perjanjian lisensi, karena sangat berpengaruh pada kualitas hubungan antara pemberi dan penerima lisensi. Mekanisme pembayaran royalty hanya dijelaskan dalam lisensi wajib saja dimana dikatakan bahwa besarnya royalty yang harus dibayarkan dan cara pembayarannya ditetapkan oleh Direktorat Jenderal. Bentuk pembayaran royalty inipun ada macamnya, ada yang dibayar sekaligus, ada juga yang dibayar menurut presentase bagi setiap satuan barang yang diproduksi, yang harganya dapat ditentukan oleh berbagai macam cara. ${ }^{65}$

\section{Keunggulan Pelaksanaan Alih teknologi Melalui Perjanjian Lisensi ${ }^{66}$}

a. Lebih mudah untuk memasuki pasar asing dengan biaya yang lebih murah, karena pemberian lisensi tidak membutuhkan investasi ataupun pengetahuan serta kekuatan pemasaran di pasar asing, karena perjanjian lisensi merupakan wahana yang berguna untuk internasionalisasi perusahaanperusahaan kecil yang terhambat dalam biaya. Selain itu, alih teknologi dengan perjanjian lisensi juga merupakan strategi untuk menduduki pasar terlebih dahulu sebelum memasuki kompetisi, khususnya apabila sumber daya pemegang paten hanya memungkinkan keterlibatan berskala penuh di pasar yang terbatas.

b. Mempunyai peluang untuk akses perolehan dan penguasaan teknologi secara cepat, karena melalui perjanjian lisensi dapat menghemat waktu serta usaha dalam riset dan pengembangan. Selain itu, perusahaan juga dapat memperoleh sumber daya pengetahuan saat proses alih teknlogi tersebut.

\footnotetext{
${ }^{65}$ Prof. Etty Susilowati, Hak Kekayaan Intelektual dan Lisensi Paten, Universitas Diponegoro, Semarang, 2013, hlm 90.

${ }^{66}$ Insan Budi Maulana, Ridwan Khairani, Nurjihad, Op Cit, hlm 62-63
} 
c. Membantu untuk menghindari regulasi Negara tuan rumah yang lebih lazim dalam modal ventura, serta dapat menghindari biaya-biaya yang berkaitan dengan bisnis luar negeri di negara yang tidak bersahabat.

\section{Kelemahan Pelaksanaan Alih Teknologi Melalui Perjanjian Lisensi ${ }^{67}$}

a. Terbentuknya competitor, karena dengan memberikan lisensi kepada sebuah perusahaan asing, perusahaan tersebut akan memperoleh pengetahuan produksi dan teknologis, sehingga sangat berpotensi untuk menjadi kompetitor di masa depan.

b. Terbatasnya hasil imbalan yang diberikannya, karena meskipun tidak ada pengeluaran modal, royalty dan pendapatan dari pemberianlisensi tidaklah mudah didapat bagi pemilik paten, yang mesti menginvestasikan waktu manajemen dan perekayasaan. Sedangkan bagi penerima paten yang biasanya berasal dari negara berkembang, mengenai aibat-akibat dari pembayaran royalty kepada negara maju, berpengaruh pada neraca pembayaran negara-negara berkembang. ${ }^{68}$

c. Meskipun dalam perjanjian lisensi menguraikan hak dan kewajiban dari kedua belah pihak, kesalahpahaman dan konflik dapat muncul dalam pelaksanaannya. Kualitas produk yang tidak konsisten untuk semua Negara disebabkan oleh longgarnya kendali mutu dapat pula merusak reputasi sebuah sebuah produk atas basis dunia

\section{KESIMPULAN}

Pelaksanaan alih teknologi melalui perjanjian lisensi paten diatur dalam Pasal 76 sampai dengan 80 Undang-Undang Nomor 13 Tahun 2016. Alih teknologi melalui perjanjian lisensi pada pelaksanaannya wajib disertai dengan ketentuan know how, karena tanpa adanya ketentuan tersebut dapat dipastikan akan mengalami banyak hambatan dan hampir tidak mungkin dapat menguasai

\footnotetext{
${ }^{67}$ http://zalirais.wordpress.com/2013/09/27/perjanjian-lisensi-license-agreement/

${ }^{68}$ R.M. Suryodiningrat, Aneka Hak Milik Perindustrian Dan Hak Paten, Tarsito, Bandung, 1994, hlm 42
} 
teknologi yang dipatenkan tersebut, karena tidak semua pengetahuan untuk melaksanakan paten tersebut diuraikan dalam deskripsi paten yang bersangkutan. Pembayaran royalty juga merupakan hal terpenting yang harus ada dalam perjanjian lisensi. Pembayaran royalty dapat dilakukan dengan dibayar sekaligus, atau dibayar menurut presentase bagi setiap satuan barang yang diproduksi. Pelaksanaan Alih teknologi melalui perjanjian lisensi juga memiliki keunggulan maupun kelemahan. Keunggulan dari alih teknologi melalui perjanjian lisensi adalah lebih mudah untuk memasuki pasar internasional dengan menghemat biaya dan waktu, serta dapat memperoleh pengetahuan mengenai teknologi secara lebih cepat, sedangkan kelemahannya adalah terbentuknya kompetitor, terbatasnya royalty, dan sering terjadi konflik pada saat pelaksanaannya. 


\section{DAFTAR PUSTAKA}

Insan Budi Maulana, Ridwan Khairani, Nurjihad. Kapita Selekta Hak Kekayaan Intelektual I. 2000. Yogyakarta

C.S.T Kansil. Hak Milik Intelektual, Paten, Merek Perusahaan, Merek Perniagaan, Hak Cipta.1990. Jakarta: Bumi Aksara

Prof. Etty Susilowati. Hak Kekayaan Intelektual dan Lisensi Paten. 2013. Semarang: Universitas Diponegoro

R.M. Suryodiningrat. Aneka Hak Milik Perindustrian Dan Hak Paten. 1994. Bandung: Tarsito

Kitab Undang-Undang Hukum Perdata

Undang-Undang Nomor 13 Tahun 2016 Tentang Paten

http://kip.bppt.go.id,/index.php?option=com_content\&view=article\&id=768\&Ite $\operatorname{mid}=248$

http://kurniowen.blogspot.com/2012/06/kontrak-lisensi-alih-teknologi-di.html

http://zalirais.wordpress.com/2013/09/27/perjanjian-lisensi-license-agreement/ 